\title{
Diode Laser Turbinate Reduction in Allergic Rhinitis: A Cross-sectional
} Study

\author{
Priyanka Gupta, ${ }^{1}$ Toran KC, ${ }^{2}$ Deepak Regmi ${ }^{3}$
}

'Department of ENT-Head and Neck Surgery, Bluecross Hospital, Kathmandu, Nepal, ${ }^{2}$ Department of ENT-Head and Neck Surgery, Nepal Mediciti Hospital, Kathmandu, Nepal, ${ }^{3}$ Department of ENT-Head and Neck Surgery, Kathmandu Medical College, Kathmandu, Nepal.

\section{ABSTRACT}

Introduction: Turbinate reduction procedures are recommended for inferior turbinate hypertrophy in allergic rhinitis that fail to respond to medical therapy. Several modalities like turbinectomy, submucosal resection and tissue ablation are available for this purpose. The study aimed to evaluate the effectiveness of diode laser in the treatment of symptomatic inferior turbinate hypertrophy in allergic rhinitis and explore complications related to the procedure.

Methods: This descriptive cross-sectional study was carried out in a tertiary care centre. The study enrolled 60 patients with inferior turbinate hypertrophy with failure of medical therapy. Inferior turbinate reduction was performed under local anaesthesia using diode laser. All the patients were evaluated subjectively for various nasal symptoms using visual analogue score scale preoperatively and during postoperative visit at three months.

Results: The age ranged from 16 to 47 years with median age of 28 years. Twenty nine were male and thirty one were female. There was significant improvement in symptoms like nasal obstruction, nasal discharge, sneezing and decreased sense of smell. Immediate post-operative pain, crusting and persistent nasal discharge were observed as complications of the procedure. However, there was no incidence of mucosal oedema and synechiae formation in our study.

Conclusions: Diode laser turbinate reduction procedure is safe, minimally invasive and effective in relieving the symptoms associated with inferior turbinate hypertrophy in allergic rhinitis resistant to medical therapy and can be performed on a day care basis under local anaesthesia.

Keywords: allergic rhinitis; diode laser; inferior turbinate hypertrophy; turbinate reduction.

\section{INTRODUCTION}

Surgery in allergic rhinitis is reserved for patients who fail to improve with medical management and have inferior turbinate hypertrophy. ${ }^{1,2}$ Tissue ablation procedures, using diode lasers, carbon dioxide lasers, argon lasers, neodymium-yttrium aluminium garnet lasers, holmiumyttrium aluminium garnet lasers, potassium-titanylphosphate lasers and radiofrequency, have been widely used in developed countries. These laser types differ on emitted laser wavelength, output power, wave emission and mode of application. ${ }^{3}$ These parameters have impact on light-tissue interactions and resulting tissue effects in the form of ablation, coagulation and carbonization. $^{4}$

Diode lasers of $940 \mathrm{~nm}, 980 \mathrm{~nm}, 470 \mathrm{~nm}$ and $1940 \mathrm{~nm}$ wavelength have been employed. ${ }^{5-10}$ Diode laser turbinate reduction (LTR) is performed as an office procedure under local anaesthesia. The operating time ranged from two to twelve minutes. $5,7,8,10,11$ Significant improvement was noted by three months time. The reported complications included intraoperative bleeding, postoperative blood mixed nasal secretions, pain,

Correspondence: Dr. Priyanka Gupta, Department of ENT-Head and Neck Surgery, Bluecross Hospital, Tripureshwor, Kathmandu, Nepal. Email: peekugupta@gmail.com, Phone: +977-9849221720. 
crusting and synechia. ${ }^{6-8,10,11}$

There are limited studies on diode LTR in Indian subcontinent. ${ }^{6-8}$ This study aimed to evaluate the efficacy of diode LTR in medical therapy resistant allergic rhinitis and encourage its use among care providers.

\section{METHODS}

This was a descriptive cross-sectional study conducted in outpatient department of ENT-Head and Neck Surgery in Kathmandu Medical College Teaching Hospital (KMCTH). KMCTH was a tertiary care centre based in Kathmandu, Nepal. The study used convenient sampling technique. The sample size was calculated by using the following formula:

Sample Size calculation (n): $z^{2} p q / e^{2}$

$=(1.645)^{2} \times 0.10(1-0.10) /(0.10)^{2}$

$=24$

where $z=$ confidence interval at $90 \%, 1.645$,

$$
\begin{aligned}
& p=\text { prevalence, } 10 \%,{ }^{12} \\
& q=1-p \\
& e=\text { margin of error }, 10 \% .
\end{aligned}
$$

The study involved sixty patients over one year period from November 2012 to November 2013. The patients of allergic rhinitis with failure of medical therapy for three consecutive months were selected for diode laser turbinate reduction (LTR) and were enrolled after informed consent. Patients with grossly deviated nasal septum, nasal polyps and history of previous nasal surgeries were excluded. Ethical clearance was obtained from ethical clearance committee of KMCTH.

Each of the nasal symptoms, including nasal obstruction, nasal secretions, sneezing, headache, decreased sense of smell and snoring, at presentation were assessed subjectively using visual analogue scale (VAS) and were scored along the scale of zero to ten. A score of zero represented no symptoms and a score of ten implied highly symptomatic. Similarly, a score of zero represented no obstruction whereas a score of ten implied complete obstruction. All the patients in the cohort underwent nasal endoscopy for baseline assessment and to rule out nasal polyposis and other relevant findings like deviated nasal septum. The patients underwent diode LTR as an office procedure with due precautions under local anaesthesia using $15 \%$ xylocaine surface spray followed by two percent xylocaine injection locally. Fox diode laser of $980 \mathrm{~nm}$ wavelength from A.R.C laser was used in contact mode with soft bending silica fibre of $600 \mu \mathrm{m}$ diameterat five watt power. Multiple linear applications, six to eight times, were made along the inferior turbinate as required over the duration of two to three minutes.
Patients were observed for half an hour for bleeding before discharge and were given acetyl salicylic acid for a day for pain relief and normal saline nasal solution for two weeks to prevent crust formation. The patients were assessed in three months follow up. During third month postoperative visit, the baseline symptoms were reassessed using VAS score. Postoperative morbidities like pain, blood mixed discharge, crusting, mucosal oedema and synechiae were also evaluated during postoperative visit with nasal endoscopy.

All the data were analysed using statistical package for social sciences 18 (SPSS 18). Both descriptive and inferential statistics were used for data analysis. In descriptive analysis, mean and standard deviation; and median and interquartile range were used. In inferential statistics, Wilcoxon Signed Rank test was used to study the efficacy of diode laser.

\section{RESULTS}

The study enrolled 29 (48\%) males and 31 (52\%) females. The age group ranged from 16 years to 47 years. The median age in the study was 28 years. Nasal obstruction was the commonest symptom and was present in $100 \%(n=60)$ of the study population followed by decreased sense of smell 35 (58.33\%), nasal discharge 18 (30\%), sneezing 17 (28.33\%), headache $9(15 \%)$ and snoring $2(3.33 \%)$ (Figure 1). The mean VAS score at presentation for nasal obstruction, decreased sense of smell, nasal discharge, sneezing, headache and snoring were 9.17, 3.78, 1.85, 2.07, 0.87 and 0.17 respectively (Table 1 ). The calculated $P$ value for improvement of symptoms at three months was found significant for each of the symptoms except snoring. Each of the symptoms consistently decreased resulting in improvement of VAS score.

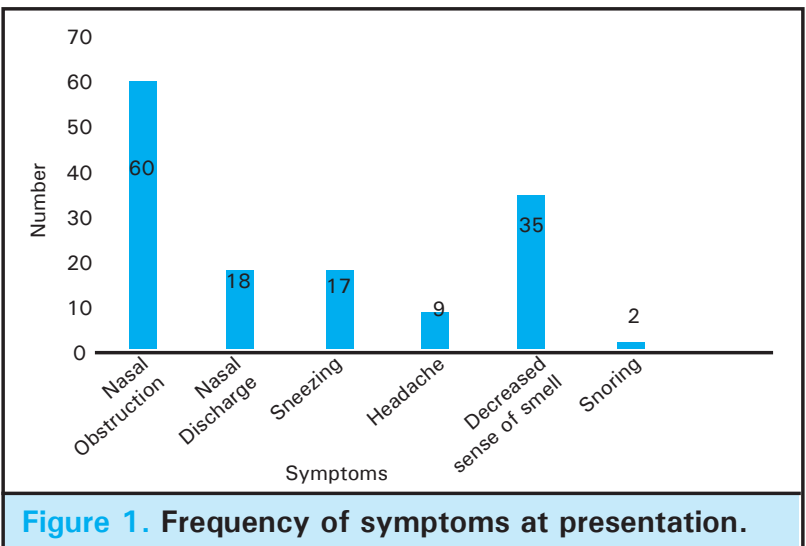


Gupta et al. Diode Laser Turbinate Reduction in Allergic Rhinitis: A Cross-sectional Study

Table 1. Visual analogue scale (VAS) score at presentation and follow up visit.

\begin{tabular}{lll}
\hline \multicolumn{1}{|c}{ Symptoms } & \multicolumn{1}{c}{$\begin{array}{c}\text { VAS at } \\
\text { presentation }\end{array}$} & $\begin{array}{c}\text { VAS at three } \\
\text { months }\end{array}$ \\
Nasal obstruction & 9.17 & 1.75 \\
Nasal discharge & 1.85 & 0.27 \\
sneezing & 2.07 & 0.00 \\
Headache & 0.87 & 0.12 \\
Snoring & 0.17 & 0.05 \\
$\begin{array}{l}\text { Decreased sense of } \\
\text { smell }\end{array}$ & 3.78 & 1.30 \\
\hline
\end{tabular}

The pain at laser site was consistently present in all the patients in the immediate post-operative period and was relieved uniformly in all the patients after sometime. Blood mixed discharge had similar course but was observed in only $22(37 \%)$ patients. Nevertheless, crusting was noticed in 39 out of $60(65 \%)$ patients at three months follow up. Mucosal oedema and synechiae were not observed in any patients during entire postoperative period (Table 2).

\begin{tabular}{|lcc|}
\hline \multicolumn{3}{|l|}{$\begin{array}{l}\text { Table 2. Frequency of postoperative morbidities at } \\
\text { three months follow up. }\end{array}$} \\
\hline Complications & Immediate & $\begin{array}{c}\text { Three month } \\
\text { postoperatively }\end{array}$ \\
$\begin{array}{l}\text { Pain } \\
\text { Blood mixed nasal } \\
\text { discharge }\end{array}$ & 60 & 0 \\
$\begin{array}{l}\text { Crusts } \\
\text { Synechiae }\end{array}$ & 0 & 9 \\
Mucosal oedema & 0 & 19 \\
\hline
\end{tabular}

\section{DISCUSSION}

The study analysed the symptoms and postoperative morbidities with diode laser turbinate reduction (LTR) procedure in patients of allergic rhinitis refractory to at least three months of medical management. Inferior turbinate hypertrophy in allergic rhinitis causes nasal obstruction and hinders quality of living causing discomfort. Significant improvement was observed in each of the nasal symptoms by the end of three months. Nevertheless, unlike other symptoms, nasal obstruction and snoring had rather slower course for improvement. This was mainly due to post-operative swelling of coagulated tissue. The coagulated tissue sloughed off within four post-operative weeks and was eventually replaced by scar tissue. Postoperative oedema and crusting might be responsible for protracted improvement in nasal obstruction and sense of smell. There was decrease in nasal discharge by end of three months of laser therapy and could be attributed to destruction of highly vascular sub-mucosa and seromucinous glands. ${ }^{8}$ No patient reported sneezing at three months follow up. This could be due to destruction of branches of posterior nasal nerve. ${ }^{8}$

No significant complications were noticed during intraoperative period. All the patient complained of some degree of pain immediately following the procedure. The study would have been more informative if postoperative pain was also measured using a standardised scale. None of the patients however complained of pain in subsequent follow ups. Parida et al reported pain in only $30 \%$ of the patients in immediate post-operative period. ${ }^{8}$ Twenty two patients $(37 \%)$ started having blood mixed nasal discharge following the procedure and nine patients $(15 \%)$ had persistent blood mixed nasal discharge by the end of three months. Nineteen out of sixty $(32 \%)$ had persistent crusting by the end of three months. The other studies with diode laser have not reported persistent nasal discharge at six months follow up. ${ }^{6-8}$ Hence, further assessment at six months follow up would have been valuable to assess nasal discharge in our study group. Mucosal oedema and synechiae formation were not observed in any patients postoperatively. The observation in the postoperative period suggested that the minimally invasive diode laser treatment was not associated with an increased risk of local infections unlike other surgical modalities.

\section{CONCLUSIONS}

The study concluded that the diode laser turbinate reduction procedure, which could be performed as a day care office procedure, was effective in allergic rhinitis refractory to medical management. Almost all the patients experienced some pain despite analgesic measures prior to procedure. Stratification of pain in immediate post-operative would have made the study more informative. Persistence of crusts in some patients at three months follow up indicated the need of further follow up.

\section{Conflict of Interest: None.}




\section{REFERENCES}

1. Seidman MD, Gurgel RK, Lin SY, Schwartz SR, Baroody FM, Bonner JR, et al. Clinical practice guideline: allergic rhinitis. Otolaryngol Head Neck Surg. 2015;152Suppl 1:S1-43. [ Full Text $\mid \underline{\text { PubMed] }}$

2. Wheatley LM, Togias A. Allergic rhinitis. N Engl J Med. 2015;372(5):456-63. [Full Text | PubMed]

3. Janda P, Sroka R, Baumgartner R, Grevers G, Leunig A. Laser treatment of hyperplastic inferior nasal turbinates: a review. Lasers Surg Med. 2001;28(5):404-13. [Full Text | PubMed]

4. Janda P, Sroka R, Mundweil B, Betz CS, Baumgartner R, Leunig A. Comparison of thermal tissue effects induced by contact application of fiber guided laser systems. Lasers Surg Med. 2003;33(2):93-101. [ㅍll Text | PubMed]

5. Havel M, Sroka R, Leunig A, Patel P, Betz CS. A double-blind, randomized, intra-individual controlled feasibility trial comparing the use of 1,470 and $940 \mathrm{~nm}$ diode laser for the treatment of hyperplastic inferior nasal turbinates. Lasers Surg Med. 2011;43(9):881-6. [Full Text | PubMed]

6. Bhandary SK, Khanna RA, Bhat VS, Aroor R. Diode laser-an ideal tool for inferior turbinate reductionin allergic rhinitis. Nitte University Journal of Health Science. 2016;6(3):27. [Full Text]

7. Hoque MR, Rasel A, Asad MK, Aich ML. Turbinoplasty of hypertrophied inferior turbinate by diode laser. Bangladesh Journal of Otorhinolaryngology. 2010;16(1):29-34. [․ㅡll Text I DOI]
8. Parida PK, Surianarayanan G, Alexander A, Saxena SK, Santhosh K. Diode laser turbinate reduction in the treatment of symptomatic inferior turbinate hypertrophy. Indian Journal of Otolaryngology and Head \& Neck Surgery. 2013;65(2):350-5. [Full Text | DOI ]

9. Cakli H, Cingi C, Güven E, Gurbuz MK, Kaya E. Diode laser treatment of hypertrophic inferior turbinates and evaluation of the results with acoustic rhinometry. Eur Arch Otorhinolaryngol. 2012;269(12):2511-7. [PubMed]

10. Kang SH, Lim S, Oh D, Kang K, Jung KJ, Kim HK, et al. Clinical Feasibility Trial of 1,940-nm Diode Laser in Korean Patients with Inferior Turbinate Hypertrophy. Medical Lasers; Engineering, Basic Research, and Clinical Application. 2015;4(2):60-4. [Full Text]

11. Caffier PP, Scherer H, Neumann K, Lück S, Enzmann $\mathrm{H}$, Haisch A. Diode laser treatment in therapy-resistant allergic rhinitis: impact on nasal obstruction and associated symptoms. Lasers Med Sci. 2011;26(1):57-67. [ubMed]

12. Katelaris $\mathrm{CH}$, Lai CK, Rhee CS, Lee SH, De Yun W, Lim-Varona L, et al. Nasal allergies in the Asian-Pacific population: results from the Allergies in Asia-Pacific Survey. Am J Rhinol Allergy. 2011;25Suppl 5:S3-15. [Full Text | $\underline{\text { PubMed | DOI] }}$

The Author(s) 2018.

This work is licensed under a Creative Commons Attribution 4.0 International License. The images or other third party material in this article are included in the article's Creative Commons license, unless indicated otherwise in the credit line; if the material is not included under the Creative Commons license, users will need to obtain permission from the license holder to reproduce the material. To view a copy of this license, visit http://creativecommons.org/licenses/by/4.0/ 